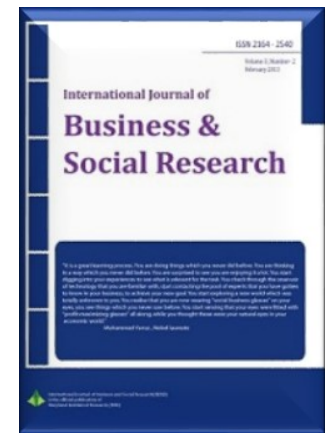

\title{
Income Inequality: Do Different Inequality Measures Show Different Impacts on Economic Growth, at the State Level? An Analysis of the State of New Jersey ${ }^{1}$
}

\author{
Bertram C. I. Okpokwasili, Ph.D. ${ }^{2}$
}

\begin{abstract}
This paper investigates whether the use of different inequality measures is instrumental in determining impact on economic growth at the State level. We find that different measures show different levels of significance with respect to economic health. We study New Jersey income distribution and shares from 1964 to 2014, using graphs and statistics. The dual analyses approach and the use of different inequality measures enabled conclusions to be reached, that only one view and one inequality measure would have made difficult, if not misleading. New Jersey Real GDP/Capita (RGC) was going up, whether or not the inequality measure was getting better. Inequality had little or no effect on the direction of the RGC. Economic Growth is not a good measure of the effects of inequality.
\end{abstract}

Keywords: Economic growth, gini coefficients, quintiles, real GDP/capita.

JEL Codes: D63, F43, C10.

Available Online: 12-01-2016

This is an open access article under Creative Commons Attribution 4.0 License, 2016.

\section{0}

INTRODUCTION

Research papers tend to fall on either side of the argument whether inequality is helpful to economic growth. Even though the Gini coefficient is the most widely used income distribution tool, other measures such as the Atkinson Index, the 20/20 measure (ratio of $1^{\text {st }}$ Quintile Mean Income/ $5^{\text {th }}$ Quintile Mean Income) amongst others, have been employed at various times. The question investigated in this paper is whether the claim of impact might depend on the inequality measure used. It is relative rather than absolute inequality that matters more on people's lives and behavior. It is of relevance, therefore

\footnotetext{
${ }^{1}$ I am grateful for the numerous changes which both the editor of the journal of business and the peer reviwers suggested in order to make this paper better in every respect. I incorporated many of them in the final copy of this paper. To the extent that this paper has any redeeming quality, the praise should go to these reviewers and the editor. I take responsibility for any shortcomings.

${ }^{2}$ Associate Professor, School of Business Administration, Georgian Court University, Lakewood, NJ
} 
that studies be made of inequality variations at the local and state levels. That is another contribution this paper makes.

The Gini coefficient, even though very widely used, has been criticized for not differentiating between different kinds of inequalities. In which case, even when two Lorenz curves intersect, indicating different inequality patterns, they may still have the same Gini Coefficients ${ }^{3}$. The Gini coefficient is said to be most appropriate for inequalities in the middle spectrum. It may have difficulties at the top or at the bottom 4 . In this study, we use the Gini, the 20/20 measure, the various ratios of the different segments of the population and income quintiles and percentages. The 20/20 measure could also be the ratio of the 5 th Quintile over the 1st. We will show that the two versions are sensitive to inequalities at different ends of the income spectrum.

There is a general agreement that in the US, at least, and in the most recent times, income inequality has grown substantially. In fact this has become a major 2016 presidential (the US) and other campaign issue 5 . But apart from politics and its implications, scholars are very much disagreed on many aspects of the inequality arguments. And these include:

- What causes the perceived income inequality in the US?

- Is the present attention given to inequality justified-is inequality harmful to growth?

- Why are scholars disagreed as to whether inequality has impact on economic development?

At the national and international levels, data is plentiful for various forms of analyses and positions. This paper seeks to use state data to explore the last 2 of the 3 questions above. One recognizes the many limitations entailed in the measurement of data on income and wealth in the country, very magnified when dealing with the states. It is also relevant to recognize that pre-tax and post-tax measurements may give different results, as well as income with or without capital gains.

We limit ourselves to pre-tax incomes, recognizing that, at the lowest levels, government transfer payments may not be fully captured as income to the poorest families. We however use total family income as determined by the Bureau of the Census, which could include total earned and unearned income.

Section 2.0 is a short review of the literature of various positions taken by researchers on income distribution and its effects.

Section 3.0, discusses the data and methodology of this paper.

Section 4.1, covers the descriptive/graphical analysis of our data on the relationship between Economic wellbeing and the Inequalities.

Section 4.2 gives the results of the empirical analysis of the relationship between economic wellbeing and income inequalities. The related tables are in Tables 1 and 2. We use the state of New Jersey experience to determine if state figures support what has been said on the national level, and what relationship, if any, exists between inequality and economic wellbeing.

Section 5.0 concludes the findings.

\subsection{PRIOR LITERATURE AND HYPOTHESIS DEVELOPMENT}

There is recently, so much interest in income distribution that many presidential statements in the most recent times have focused on the lopsided distribution of income in the United States. The heated debate on the share of national income that goes to the top $1 \%$ of the population prompted many days of sit-ins and demonstrations on Wall Street in the months preceding the presidential election of 2012. The campers claimed they were the 99 Percenters, the bottom portion of the population whose share of income the One Percenters were taking. Writing in the Los Angeles Times of February 2015, David Lauter headlined his piece as "income inequality emerges as key issue in 2016 presidential campaign". He goes

\footnotetext{
3 Fernando G De Maio, 'Income inequality measures', www.jech.com, J. Epidemical Community Health 2007

${ }^{4}$ Fernado Maio, opcit.

5 See Mother Jones publication of April 2, 2015- "Bernie Sanders goes Biblical on Income Inequality" by Josh Harkinson
} 
on to quote Gallup Polls that " Although economic growth has resumed, the stock market has soared into record territory, and the number of Americans filing new claims for unemployment benefits has fallen to its lowest level in nearly 15 years, income has remained stuck except for those at the very top." 6 Interest and debate on Income Distribution are an age old intractable, yet exciting academic and social question, with as many researchers on one side as there are on the other side. The discussion on Income Distribution was very much geared toward the economic growth of developing nations. Simon Kuznets in his seminal address to the American Economic Society asked "Does inequality in the distribution of income increase or decrease in the course of a country's economic growth. What factors determine the secular level and trends of income inequalities"'.

Kuznets would go on to observe that inequitable distribution of income deterred economic development in a developing country, and so would be of a negative consequence. In developed countries however, inequitable distribution of income would favor economic growth. His analysis would lead to what was called the Kuznets Curve. The curve which is like an inverted $U$ shape, would have Kuznets hypothesizing that "as economic growth / development increases, inequalities first go up and then come down" 8 Kuznets would later abandon this hypothesis, for lack of plausible data, even as many economists and researchers lined up on both sides of the hypothesis.

Similar to the Kuznets curve debate, income distribution has had supporters and detractors- those who assert that income inequality is very harmful to economic growth and development (Wilkinson and Picket, the Spirit Level, 2009), and those who maintain that inequality is necessary for robust economic growth, and is good for the country (Barro, 2000) ${ }^{9}$, also strongly argued for by economists at the Manhattan Institite $(2014)^{10}$

Nancy Birdsall11 extensively explored the literature on the development and lack thereof of many Asian and Latin American countries. Whether or not inequality contributes to economic development would depend on other economic and political institutions in the country, she claims. Where institutions are weak, and politicians seem not to care for the welfare of the poor, inequality grows at the expense of the poor, and development lags behind. Where more democratic institutions thrive, like the early northern farmers in the US, where labor was not as abundant as the slavery in the south, property rights were more broad-based, and thriving smallholder class supported public financing of education, thus creating local governments that were accountable to most of the citizens. In this setting equitable distribution of income enabled broad based growth, and stronger institutions. ${ }^{12}$ Robert Barro (2000), said Birdsall, had shown structural differences in the relationship between inequality and growth in the developed and undeveloped economies. Barro apparently showed that in higher income developed countries, inequality tended to be associated with higher growth, whereas in lower income developing countries, inequality tended to be associated with lower growth rates.

Birdsall discusses what she called "constructive" and "destructive" inequality. Constructive inequality is income inequality that reflects solely differences in individuals' responses to equal incentives or opportunities, and is consistent with efficient resource allocations. "Destructive" inequality on the other hand reflects inefficient resource allocation to the rich, which has the effect of encouraging economic discrimination and reducing the incentive to invest or take advantage of economic opportunities to contribute productively. ${ }^{13}$

\footnotetext{
${ }^{6}$ David Lauter: Income Inequality emerges as key issue in 2026 presidential campaign, LA Times, Feb. 5, 2015

7 Simon Kuznets: Economic Growth and Income Inequality; American Economic Review, March 1955, Number 1

8 Dan Hirschman: On the Origins of the Kuznets Curve / A (Budding) Sociologist Commonplace Book, http://asociologist.com/2013/03/21 on-the-origins-of-the-Kuznets-curve

99 Robert Barro found that in developed economies, inequality was helpful to growth, but harmful in developing ones.

${ }^{10}$ Eight economists, Gerald Auten of the US Treasury Dept. and others argue the positive effect of inequality.

${ }^{11}$ Nancy Birdsall_ Income Distribution: Effects on Growth and Development, Center for Global Development, Working Paper Number 118, April 2007.

${ }^{12}$ Nancy Birdsall- Income Distribution: Effects on Growth and Development

13 Nancy Birdsall
} 
Rebecca Blank and David Card used regional data in the US to study the causes of income inequality in the US. In a multiple regression of unemployment as the dependent variable and mean quintile incomes of the five quintiles over the period 1967 to 1991 as independent variables, Blank and Card would seem to assert that there was little or no relationship between unemployment and income shares. They would also indicate that if unemployment had any effect on income shares, it would seem to happen more after 1979 than before.

Black and Card would go on to show that wage dispersion, measured as standard deviation of log wages, has significant relationship to income shares. They would show that higher wage dispersion had a negative effect on low income earnings of families, and a positive effect on higher income earnings ${ }^{14}$ Black and Card would claim that "The growth in earnings and income that occurs with a rise in median wages leads to some equalization, with redistribution of income away from the top quintile, and towards the second and third quintiles. The effect of wage dispersion is more clearly redistributive and is disequalizing"'15

A book- "The Spirit Level: Why more equal societies almost always do better" by two British epidemiologists, Richard Wilkinson and Kate Picket, in March 2009, attributed all social ills to income inequality. They assert that ills ranging from infant mortality to shortened life span were all a result of inequitable distribution of income. This book was very highly received in Britain and various other social circles. It has also been criticized very strongly for lack of statistical data collection honesty and procedural miscalculations. ${ }^{16}$

In "Income Inequality in New Jersey: The Growing Divide and Its Consequences", the Legal Services of New Jersey Poverty Research Institute (LSNJ) would quote Wilkinson and Picket extensively as a proof of the damage inequitable distribution of income in New Jersey is doing to New Jersey residents. ${ }^{17}$ Some of these assertions would need to be investigated further.

The Manhattan Institute in its May $2014 \mathrm{E} / 21$ Economic Policy for the $21^{\text {st }}$ Century argues many aspects of inequality - what in the opinion of many of these economists may be facts and fiction ${ }^{18}$. Eight different economists explored various aspects of inequality. But many of these are from the viewpoint that income inequality is not as bad as it seems. And some of the quotations reflecting the observations made are indeed interesting, to say the least: Professor Bruce Meyer quotes "The level of inequality is much lower for consumption than income, and since 1980, consumption inequality has risen considerably less than income inequality". Professor Philip Amour quotes in the same publication- "A shocking result emerges: from 1987 to 2007, the incomes of the bottom and middle fifth rose (by 13 percent and 6 percent), but the income of the top 5 percent declined by 5 percent- Inequality- even between the top and everyone else- fell”'

Much has been written and suggested as to why income inequality has grown in the US in the last quarter of the $20^{\text {th }}$ Century. Many of these point to increasing wage dispersion (Blank and Card, 1993; Picketty and Saez, Feb. 2003). Picketty and Saez suggest that whereas pre-World War II top income shares were accounted for by capital accumulation, which suffered much decline because of the shocks of war and depression, from which it never recovered fully, top income shares since 1970's have reflected higher wages for CEO's and top business management. These higher earnings have persisted because the society tolerated such incomes, in addition to decline in progressive taxation since the $1980^{\prime} \mathrm{s}^{20}$. Such high

\footnotetext{
14 Rebecca Blank and David Card: Poverty, Income Distribution and Growth: Are They Still Connected? Brookings Papers on Economic Activity, Vol.1993, No.2, page 310.

15 Blank and Card

${ }^{16}$ Milos Simic- "A critical reading of the Spirit Level: why equality is better for everyone, R Wilkinson and K. Pikette, January 2012 "

17 The Inaugural Annual Report from the Legal Services of New Jersey Poverty Research Institute, July 2012, pages 8 and 10

18 The Manhattan Institute- E/21 Economic Policies for the $21^{\text {st }}$ Century- "Income Inequality in America Fact and Fiction", No. 1, May 2014

19 The Manhattan Institute, opcit.

20 Picketty and Saez, February 2003.
} 
incomes have helped fuel the growth in inequality in the US compared to the rest of the developed Western World. The reduction in union power in the US has also been mentioned as responsible for the rise in income inequality. There is hope, Picketty and Saez would suggest- for more progressive taxation in the future to stem the tide of inequality.

\subsection{RESEARCH DATA METHODOLOGY}

This study uses data from 1964 through 2014 of household incomes in New Jersey, derived from the March CPS (Current Population Survey) Data of the US Bureau of the Census, stored by IPUMS (Integrated Public Use Microdata Series) ${ }^{21}$.

The data retrieved had to be sorted by years and in ascending family income order. For each year, we would break down the data in 5 income categories (called quintiles for $1 / 5$ of the population), designating the income segments that would constitute the basis for our study. Excel's Descriptive Statistics function would be used to calculate the mean and median of each quintile.

Mark Frank had derived state inequality measures ("A New State -Level Panel of Income Inequality Measures Over the Period 1916- 2005", 2008), This had been updated to 2012 by a later publication ${ }^{22}$. So it was possible to get the inequalities (the Gini, Atkin 05 etc), other than the 20/20 measures, from this panel. The 20/20 ( $1^{\text {st }}$ Quintile Mean $/ 5^{\text {th }}$ Quintile Mean) measures were calculated from our IPUMS income figures.

GDP and Personal Income figures for New Jersey were derived from various editions of the Bureau of Labor Analysis and Bureau of Economic Analysis publications. Where necessary, we reduced all the data on GDP and Personal Income to 2009 dollar denominated figures, using consumer price indexes. GDP calculation for the state is different from GDP calculation for the national economy. The major components of National GDP calculations are Consumption, Gross Investment, Government Expenditures and Net Exports. For the state, it's mainly a summation of value add for the different businesses. State GDP is calculated as the sum of employee compensation, taxes on production and imports, subsidies and gross operating surplus. ${ }^{23}$

First we show graphical relationships between incomes, broken down by quintiles, and state GDP/Capita. This is done at the beginning of section 4. Then we do statistical analyses using Ordinary Least Squares Multiple Regressions, based on both the modified Solow model and the modified Cobb-Douglas Production Functions. These are properly described in the sections. We are not interested, for this study at this time, in causation, we are interested in relationships, if they exist, between economic growth and various inequality distributions. We are also interested in whether it is possible that using different inequality measures might show different levels of statistically significant relationships. Personal income (employee compensation) is the major component in state GDP calculations. It accounts for about $60 \%$ of the state GDP ${ }^{24}$

We measure the relationship between the state GDP/Capita, the general measure of the economic health of the state, the personal income per capita and various inequality measures, including: the 20/20 (the 1st quintile /the 5th quintile) means, the Gini and the Atkinson coefficients. We use either economic growth (change in Real GDP/Capita) or simply Real GDP/Capita, to represent economic wellbeing in this paper. We recognize, however, that economic growth is not necessarily the same as economic development, nor are we under any illusions that growth represents wellbeing for all25.

\footnotetext{
${ }^{21}$ https://USA-IPUMS.org/USA

${ }^{22}$ Mark Frank and Sommeiller- Price Series, Annual Top Income Measures for each state 1917-2012

23 Experimental Estimates of Gross Domestic Product by State (GDP by State) for years 1963etc., Bureau of Economic Analysis, US Department of Commerce, 1985

${ }^{24}$ BEA (2006) GDP by State Estimation Methodology, page 7

25 Please see Amtya Sen "Freedom as Development"1997, or Bertram Okpokwasili "economic development vs economic growth", 2007
} 


\subsection{STATE-LEVEL GDP/CAPITA VS PERSONAL INCOME AND INCOME INEQUALITIES}

\subsection{DESCRIPTIVE ANALYSIS}

Descriptive analysis gives an intuitive view of the relationships between different income shares and economic or social parameters. These relationships may not be adequately captured by regression or other mathematical analyses.

Fig.4a demonstrates the relative growth of the mean incomes of the 5 quintiles. The bottom quintile grew, albeit very slowly, until 2010 and went down from there. The top two quintiles have grown considerably, apparently at the expense of the bottom two quintiles. All three middle quintiles grew slowly over the period. The bottom quintile grew until 2010, and started a downward trend. The top $\left(5^{\text {th }}\right)$ quintile grew very quickly through 2010, went down in 2011, grew in 2012 and 2013, and slowed down in 2014.

Figure $4 \mathrm{~b}$ demonstrates graphically how the mean incomes of the bottom $20 \%$ of New Jersey residents have varied with the top $20 \%$. The figure would be much worse when the lowest $10 \%$ is compared to the top $10 \%$ or $5 \%$. It looked like the gain at the bottom in the 1960's lost ground consistently thereafter to 2014. Income inequality has grown consistently since about 1980

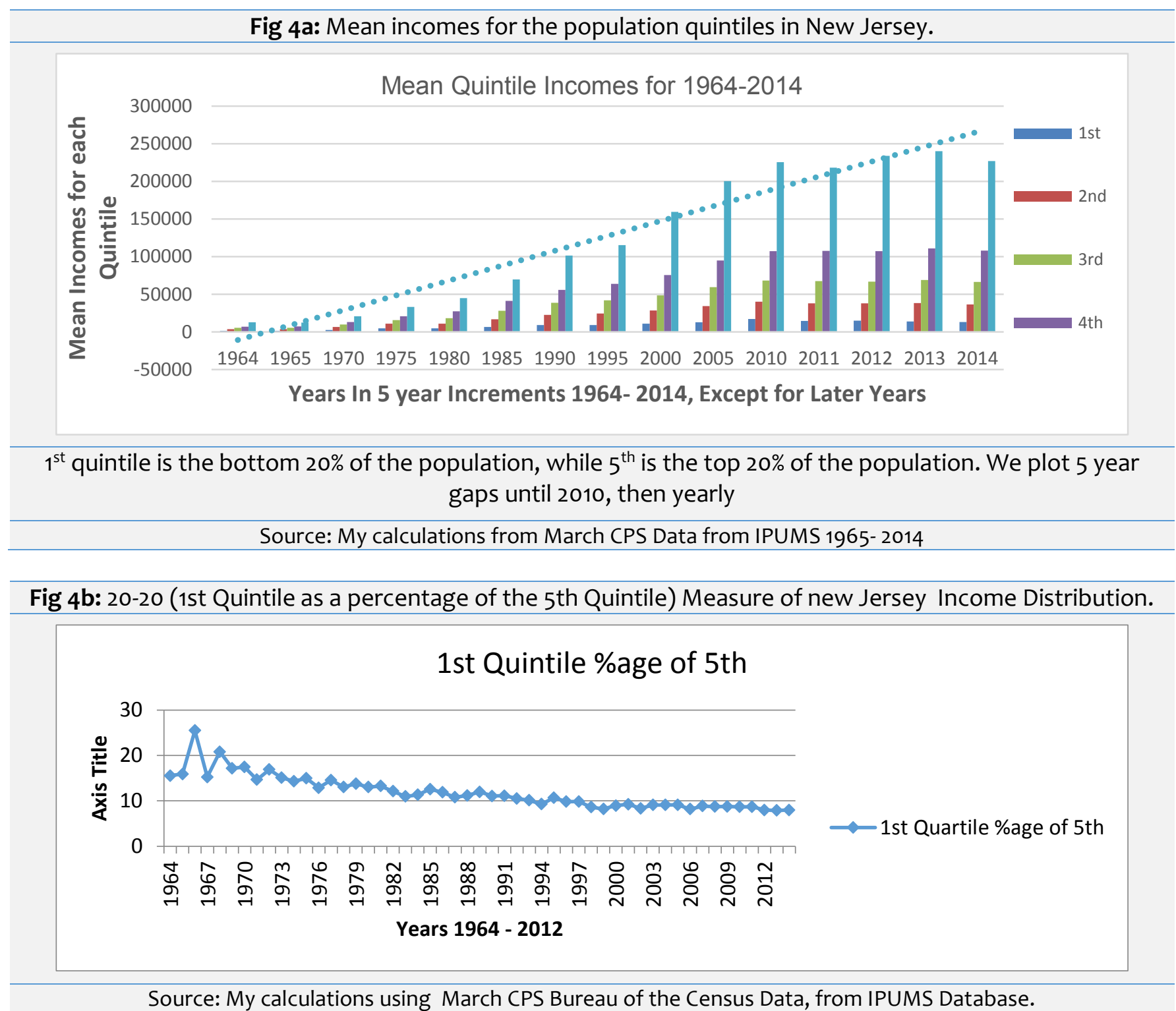


Fig $4 \mathrm{C}$ gives a graphical demonstration of the movement of Real GDP/Capita versus the three measures of inequality (the 20/20 not in percent, the Gini and the Atkino5 (in \%age terms) over the study period. It is very clear that the Gini and the Atkin 05 were moving higher along with the Real GDP/Capita. That is the way it should be if inequality worsened throughout the period, which would be what the two measures indicated. However, the 20/20 measure was not showing what the Gini and Atkino5 were showing. The 20/20 measure showed that for the $1964-1982$ period, income inequality was not getting any worse, in fact it was getting better most of that time (hovering around $11.6 \%$ to $13.3 \%$ ). But from 1983 to 2012, with the exception of 2001 , inequality had gone from $12.7 \%$ down to $6.4 \%{ }^{26}$

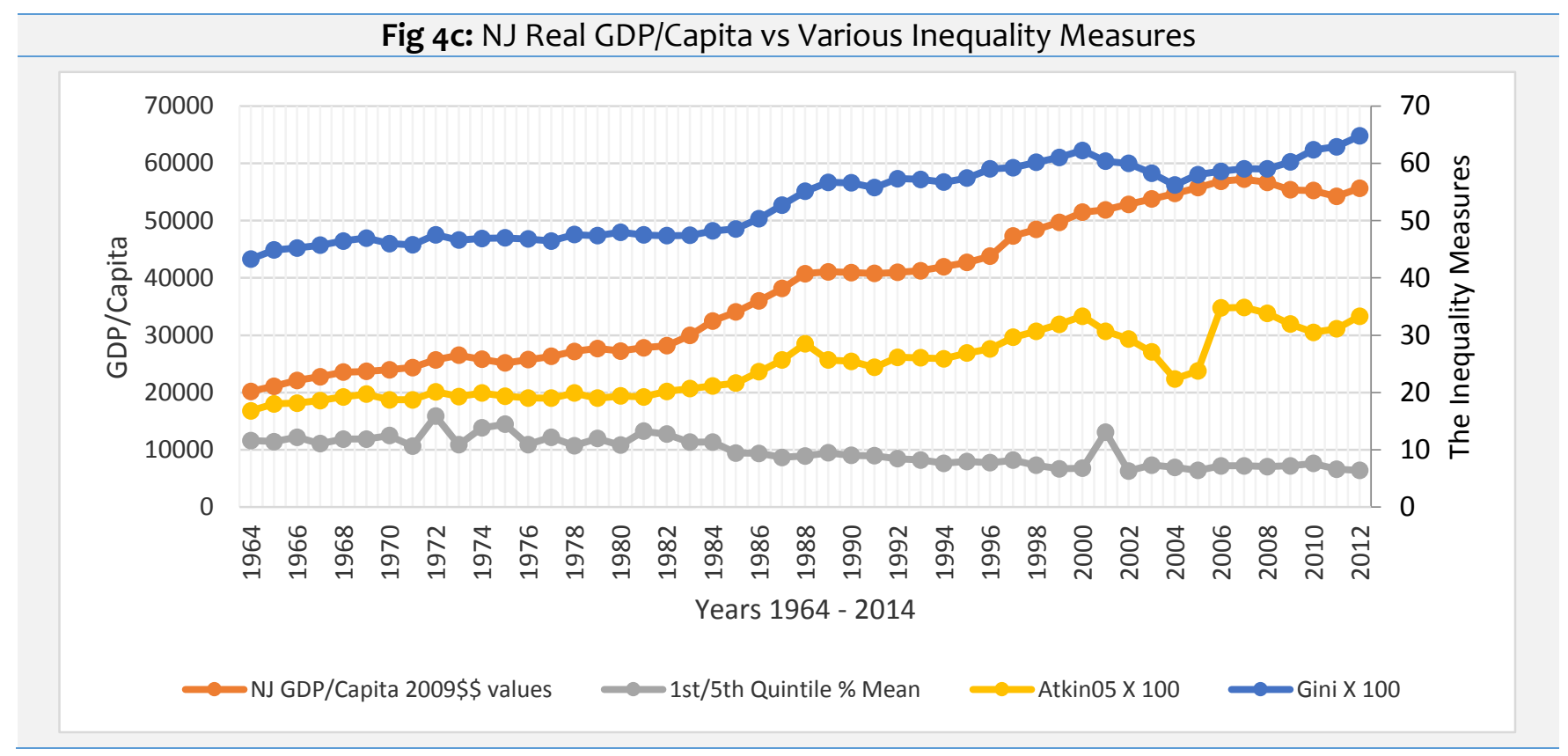

Figures $4 \mathrm{~d}$ to $4 \mathrm{f}$ give graphical relationships between Real GDP/Capita (Real with 2009 dollars) and individual inequality measures. One would expect that growth in GDP/Capita would enable the 20/20 ratio (measured by the ratio of the 1st to the 5th quintiles) to go up, indicating the narrowing of the gap between the lowest earning quintile and the top earning quintile. If however this ratio continues to decrease, one would surmise that increasing GDP/Capita over the years seemed not to have a helpful impact on the lot of the bottom earners. We do the same with the Gini coefficient and the Atkino5 measure.

A look at Figure 4d, the relationship between Real GDP/Capita and the 20/20 measure of income inequality, shows what looks to us as a mixed relationship, in that between 1964 and 1980, this ratio fluctuated between $12 \%$ and $14 \%$, but an the average tended to go up, as GDP/Capita was going up. After 1980 , one observes a downward trend in the ratio for a while (between1981 and 2000) as GDP/Capita continued on an upward trend. The 20/20 ratio spikes up in the year 2001, and remains relatively flat through 2012, going down fractionally as GDP/Capita kept an upward trend.

The Gini Coefficient, in Fig 4e moves in a direct relationship with GDP/Capita from 1964 to 2008. Then there seemed to be a divergence, the Gini increasing through 2012, while the GDP/Capita, for the most part, goes in a downward direction.

The Atkins in Fig 4f, moved directly with the GDP/Capita measure except for the three years of 2003 through 2005.

The two major objectives of this paper are; one to evaluate, using state data over the years, whether increasing income inequality is helpful or unhelpful to economic growth/economic wellbeing, and

\footnotetext{
${ }^{26}$ Note that for the $20 / 20$ measure lower percentages indicate worsening inequality, since we are dividing the $1^{\text {st }}$ quintile by the $5^{\text {th }}$ quintile.
} 
secondly whether the use of different measures of income distribution could led us to different conclusions on this issue.

Given the figures we have just evaluated, we are able to answer the second question better than the first at this juncture. The movements of the three measures of inequality with respect to GDP/Capita are different. The 20/20 measure is definitely moving in the opposite direction as the GDP/Capita. Generally, the trend in GDP/Capita has been upward, while the trend in the 20/20 measure has been downward. So one could say, using these figures, that in New Jersey over the period in question, the bottom fifth has gotten lower proportion of the income than the top fifth, even as per capita income has increased.

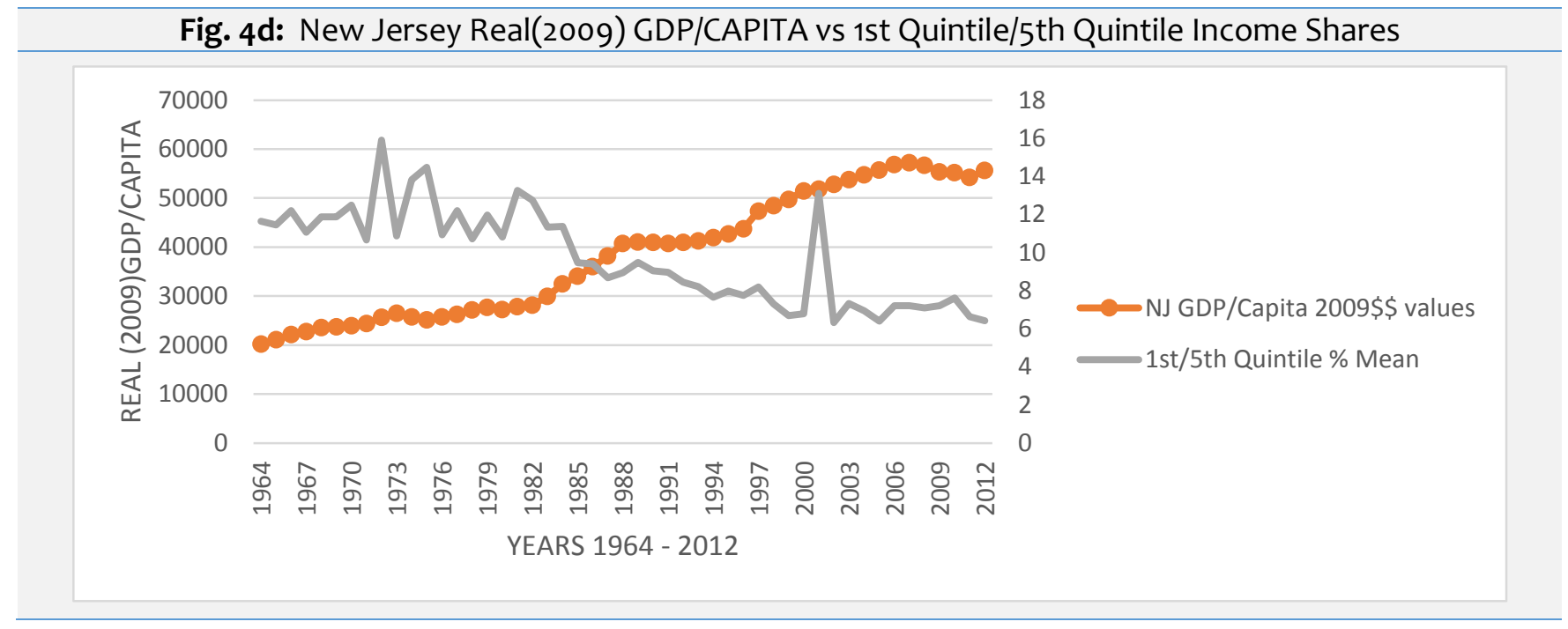

The Gini coefficient, on the other hand moved in direct relationship with the per capita GDP for most of the period in question. The Gini went up as per capita GDP increased from 1964 to 2003. One sees that as the Gini went up after 2003, the GDP/Capita went down. There were various periods where the Gini went up, while GDP/Capita went down - 1988 to 1997 for instance. The Gini would tend to show no letting off in worsening inequality over the years.

Fig 4e: NJ GDP/Capita vs Gini Coefficient For 1964-2012

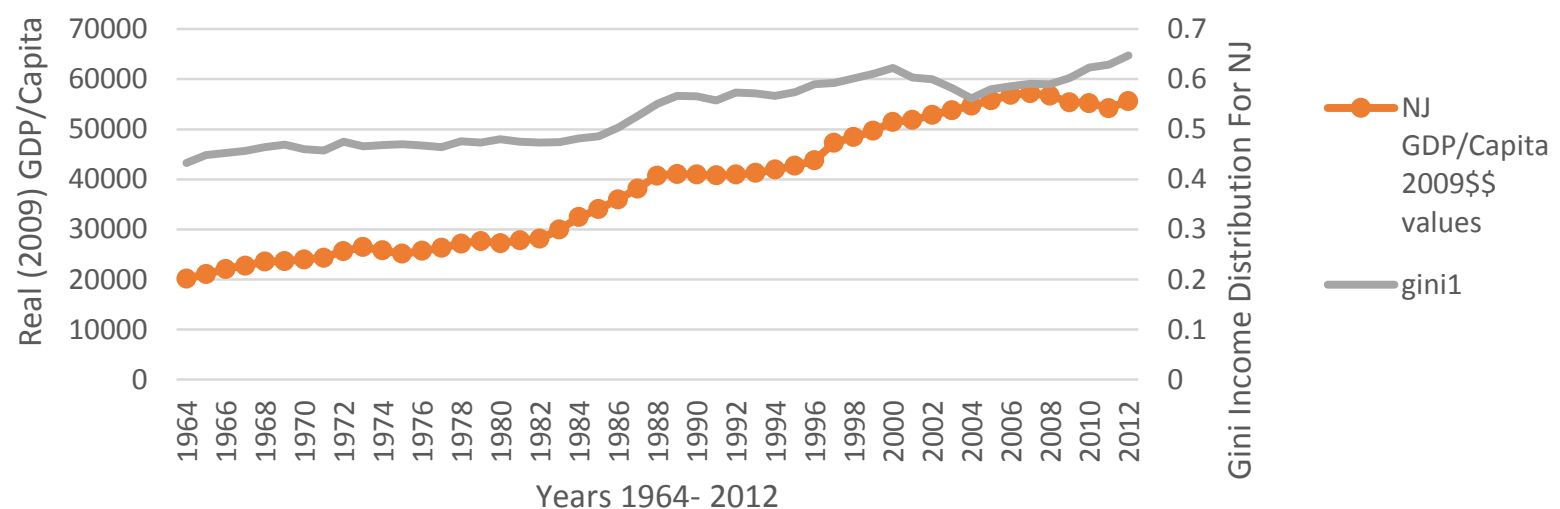

But even though we could have arrived at different conclusions using the two measures of inequality for various time frames, the long term trend for both would tend to give the same indication, namely that over the period in question income inequality increased even as the GDP/Capita increased.

The Atkino5 tended to give the same pattern as the Gini, except that from 2003, the Atkins would seem to move directly with GDP/Capita, while Gini would move in opposite direction. Between 1964 and 1985, whereas the Gini showed almost a flat (or rather unchanging) pattern of inequality, the 20/20 measure 
showed an irregular pattern of the relationship between the quintiles. In a number of cases showing improvement (or higher ratios), and in other cases maintaining a downward trend. After 1985, but for one spike upwards in the year 2000, it was generally downward, indicating increasing inequality. The Atkins would, except in 2003, show that it moved in the same direction as the GDP/Capita, increasing inequality as the economy grew.

Fig 4f: NJ Real GDP/Capita vs The Atkins Measure of Income Inequality

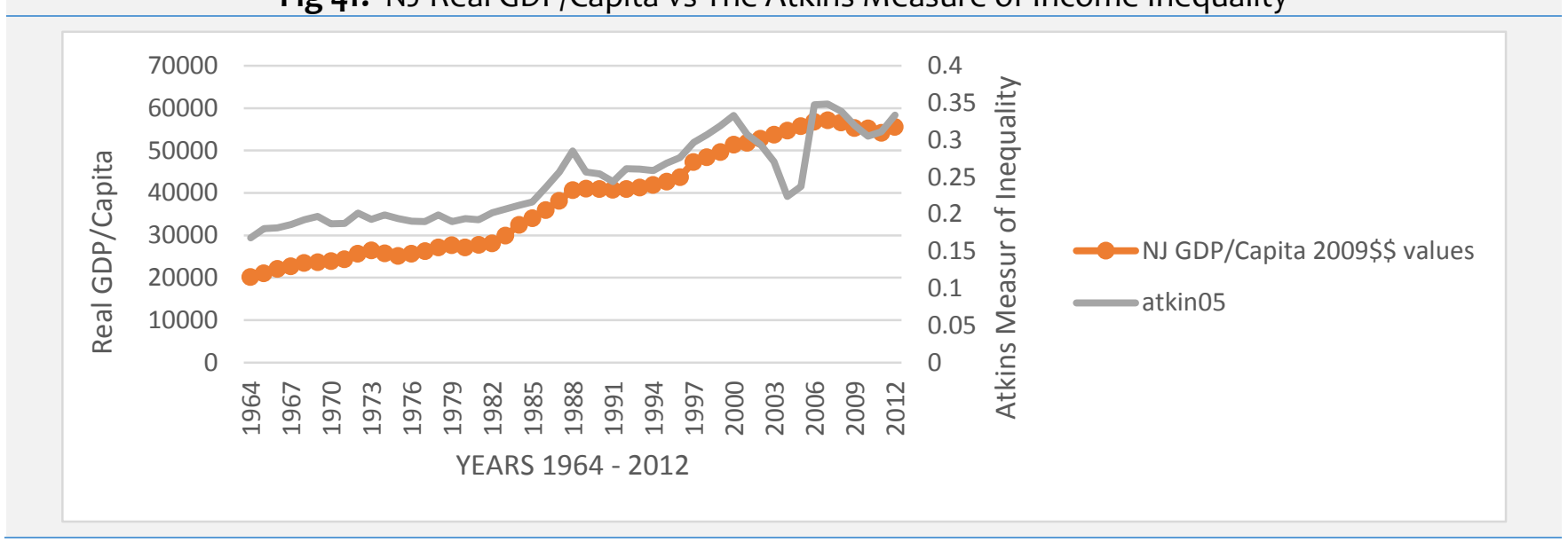

\subsection{MAIN STATISTICAL RESULTS}

This section gives the results of the various statistical analyses we did of the relationship between GDP/Capita, Personal Income and various income inequalities (the 20/20 measure, the Gini and the Atkino5 indexes). GDP/Capita measures the wellbeing of the economy, whether it is at the national level or at the State level. Even though the inequality measures we used were mainly the three mentioned above, we did explore such measures as the $5 \%$ over the $1^{\text {st }}$ quintile, and $10 \%$ over the $1^{\text {st }}$ quintile.

We did in some cases look at the ratio of the $5^{\text {th }}$ quintile over the 1st quintile, rather than the reverse as we stated earlier. We had thought that both measured exactly the same thing, except one was the reverse of the other. We were surprised to see that their roles were quite different in the measurements. They exhibited different levels of significance.

Equation $4 \mathrm{G} 1$ is the untransformed version of the relationships we explore. These are reflected in Table1.

$Y=\beta_{0}+\beta_{i} X_{i}+\ldots+\varepsilon_{i} \quad-\ldots 1$

The Natural Log Transformation of $4 \mathrm{G}_{1}$ is reflected in equation $4 \mathrm{G}_{2}$, and the models in Table-2 give our results.

$\begin{array}{rlll}\operatorname{Ln} Y= & \beta_{0}+\beta_{i} \operatorname{Ln} X_{i}+\beta j X j+ & & \\ \text { Where } Y & = & \text { Real GDP/Capita } \\ X_{1} & = & \text { Real Personal Income/Capita } \\ X_{2} & = & \text { 1st Quintile Mean/5th Quintile Mean, known as 20/20 measure. } \\ X_{3} & = & \text { The Gini Coefficient measure of inequality } \\ X_{4} & = & \text { The Atkins measure of inequality } \\ X_{5} & = & 5^{\text {th }} \text { Quintile } / 1^{\text {st }} \text { Quintile } \\ X_{6} & = & \text { Top } 10 \% / 1^{\text {st }} \text { Quintile Measure of Distribution } \\ X_{7} & = & \text { Top } 5 \% / 1^{\text {st }} \text { Quintile Measure of Distribution } \\ \varepsilon_{i} & = & \text { The error term }\end{array}$

Various versions of equation 4G1 are explored, using Real (\$2009) GDP/Capita as dependent variable, versus New Jersey Personal Income/Capita and various inequality measures (the 20/20 measure, the Gini coefficients, the Atkino5 measures, $10 \% / 1^{\text {st }}$ Quintile and $5 \% / 1^{\text {st }}$ Quintile) as independent variables. The statistical output is shown in Table 1. The transformed model of equation 4G1, given in equation 4G2, with 
various logarithmic transformations of the Real GDP/Capita and the associated independent variables, are explored also, and the statistical outputs are shown in Tablez.

Table A-1, Models 1 through 8 reflect different measures of Inequality added to Personal Income/Capita, regressed against Real GDP/Capita for 1964 to 2012.

In all the models, the 20/20 measure shows a negative but statistically significant relationship (at the $95 \%$ level) with the economy measure of Real GDP/Capita. This is in agreement with the visual diagram shown in Fig 4e. For most of $1964-2012$, the GDP/Person was on the rise. For most of that time, the 20/20 ratio was on the decline. Between 1964 and 1982, the 20/20 ratio had various up and down periods. The 20/20 ratio would seem, for this $64-82$ period to fluctuate within a level range- between $11 \%$ and $15 \%$. After 1982 , the downward spiral had taken the ratio from $12 \%-6 \%$. This negative/indirect relationship would seem to support the theory that inequality is indeed helpful to growth in a developed setting. But this is just using the quintiles for which the top quintile contains $20 \%$ of the population. The measure with the top $5 \%$ or $1 \%$ might be different.

The Gini Coefficient, unlike the 20/20 measure, exhibited a direct relationship with Real GDP/Capita throughout the study period, except for a brief reversal between 2007 and 2010, during which period the Gini continued in an upward direction even as the economy headed downward. Once again indicating that higher inequality, measured by the Gini coefficient, would seem to be helpful to economic growth in this state setting. In certain periods when the 20/20 measure showed reduction in inequality, the Gini still indicated worsening inequality, as was the case between 1964 and 1982, and between 2007 and 2010 (Fig. 4f). The Atkins index showed a positive relationship, though statistically insignificant (at $90 \%$ and above) with Real GDP/Capita.

The 20/20 measure we used was the percentage version of the Mean of the $1^{\text {st }}$ Quintile divided by the mean of the $5^{\text {th }}$ Quintile. We used the raw decimals also in the analysis, but found no difference in the statistical significance of the model. The only difference was that the coefficient of the variable was multiplied by 100 in the non-percentage version.

In other cases, we changed the 20/20 variable to represent the $5^{\text {th }}$ Quintile divided by the $1^{\text {st }}$ Quintile. This showed substantially different statistical significance and numbers from the $1^{\text {st }} / 5^{\text {th }}$ measure. There was a difference depending on which ratio was used as the 20/20 measure of inequality. This was also reflected in the graphical representations. It made some sense in that, of the two measures of 20/20 inequality, one $\left(1^{\text {st }} / 5^{\text {th }}\right)$ would represent a negative relationship with GDP growth. That is inequality would seem to be increasing when this measure is going down. The other $\left(5^{\text {th }} / 1^{\text {st }}\right)$ would show a direct relationship with increase in GDP/Capita, which means that when this ratio is increasing, inequality is increasing, the same type of measure the Gini and the Atkins05 would seem to show.

For an evaluation of our statistical analyses, we start with the:

Reference Model of Table1, the relationship between Real GDP/Capita (RGC) and Real Personal Income/Capita (RPC). We chose this as a reference, since we know that RPC would move in the same direction as RGC, since RPC is the major component of State RGC.

The equation for the reference model is approximately:

1.RGC $=-622.6+1.118 R P C+\varepsilon$

Since the constant term is not significant, it could, for all practical purposes be assumed to be close to zero. So our reference equation shows $1 . \mathrm{RPC}=.9009 \mathrm{RGC}$. One percentage change in the RPC changes RGC by $90 \%$.

The adjusted coefficient of determination is $99.08 \%$, and the beta weight is 0.9955 .

What we seek in evaluating the inequality measurements on top of the RPC is their statistical significance in relation to RGC, and the possible differences in explaining the dependent variable, made by them individually and together.

Model1: Included the 20/20 ( $1^{\text {st }}$ Quintile $/ 5^{\text {th }}$ Quintile) inequality measure with the RPC as independent variables. 
The resulting equation was RGC $=4606+1.06 \mathrm{RPC}-325.8(20 / 20)$

The adjusted coefficient of determination $\left(R^{2}\right)$ was $99.21 \%$, and the betas were -0.0644 for $20 / 20$, and 0.94 for RPC. The constant term was statistically significant, we cannot assume that it was zero. The 20/20 inequality showed a negative relationship with RGC, and showed that while it's effect is relatively very small on RGC, it has a negative effect nevertheless. A unit change in 20/20 would have the effect of changing RGC, albeit by a small amount. A $1 \%$ change in the inequality would change RGC by about $0.003 \%$. The residuals showed Durbin - Watson statistic of 0.7437 , an indication of slight autocorrelation in the independent variables. 2 would have been an ideal for no autocorrelation, and o would be positive autocorrelation. The Variance Inflation statistics were 3.0 for both independent variables. A figure more than ten would have been indicative of serious collinearity problems. As small as the impact of 20/20 is on RGC (Real GDP/Capita), it is nevertheless negative- an increase in the inequality increases GDP.

Model 2: Combined the Gini coefficient with RPC (Real Personal Income/Capita) as independent variables. The Gini did not show any statistical significance. The $\mathrm{R}^{2}$ at $99.10 \%$, indicating much less influence on RGC. The beta weight of the Gini was essentially the same as the 20/20, at 0.0616. The relationship with RGC is positive, indicating increase in one resulting in an increase in the other. An increase in Gini, however, is indicative of higher inequality in the state. One wonders if this might be the reason that Kuznets and others felt that increase in inequality was helpful to growth in developed economies.

Model 3: Included the Atkinso5 inequality index controlling for the RPC as independent variables. The Atkin 05 variable was not significant at $95 \%$ or $90 \%$ level, showed lower $R^{2}$ at $99.06 \%$, and a beta-weight of 0.0074 .

\begin{tabular}{|c|c|c|c|c|c|c|c|c|}
\hline \multicolumn{9}{|c|}{$\begin{array}{l}\text { Table 01: Equation G1 untransformed GDP/Capita Dependent Variable } \\
\text { Real (\$2009) GDP/Capita against Real Personal Income/Capita, Various Measures of Inequality }\end{array}$} \\
\hline Variables & & $\begin{array}{r}\text { Reference } \\
\text { Model } \\
\text { (GDP vs PI }\end{array}$ & $\begin{array}{r}\text { Module } 1 \\
\text { with } 20 / 20\end{array}$ & $\begin{array}{r}\text { Module } 2 \\
\text { with the } \\
\text { Gini }\end{array}$ & $\begin{array}{r}\text { Module } 3 \\
\text { with the } \\
\text { Atkins }\end{array}$ & $\begin{array}{l}\text { Module } 4 \text { with } \\
\text { Atkins \& } 20 / 20\end{array}$ & $\begin{array}{r}\text { Module } 5 \\
\text { with } \\
\text { 20/20, Gini }\end{array}$ & $\begin{array}{r}\text { Module } 6 \text { with } \\
\text { 20/20, Gini \& } \\
\text { Atkins }\end{array}$ \\
\hline Intercept & $\mathrm{B}_{0}$ & $\begin{array}{r}-622.5 \\
(-1.0984)\end{array}$ & $\begin{array}{l}4606.25 \\
(2.43)^{* *}\end{array}$ & $\begin{array}{r}-4800.6 \\
(-1.58)\end{array}$ & $\begin{array}{r}-772.4 \\
(-0.834)\end{array}$ & $\begin{array}{r}4550.123 \\
(2.201)^{* *}\end{array}$ & $\begin{array}{r}1859.15 \\
-0.482\end{array}$ & $\begin{array}{l}1475.5 \\
-0.366\end{array}$ \\
\hline $\begin{array}{l}\text { Real Personal } \\
\text { Income/Capita }\end{array}$ & $\mathrm{X}_{1}$ & $\begin{array}{r}1.119 \\
(72.06)^{* *}\end{array}$ & $(42.06)^{* *}$ & $\begin{array}{r}1.053 \\
(21.3)^{* *}\end{array}$ & $\begin{array}{r}1.1112 \\
(27.6)^{* *}\end{array}$ & $\begin{array}{r}1.057 \\
(25.13)^{* *}\end{array}$ & $\begin{array}{r}1.028 \\
(21.44)^{* *}\end{array}$ & $\begin{array}{r}1.032 \\
(20.35)^{* *}\end{array}$ \\
\hline 1st/5th Quintiles & $X_{2}$ & & $\begin{array}{r}-325.8 \\
(-2.87)^{* * *}\end{array}$ & & & $\begin{array}{r}-325.37 \\
(-2.83)^{* * *}\end{array}$ & $\begin{array}{r}-302.72 \\
(-2.58)^{* * *}\end{array}$ & $\begin{array}{l}-299.28 \\
(-2.52)^{* *}\end{array}$ \\
\hline $\begin{array}{l}\text { The Gini } \\
\text { Coefficient }\end{array}$ & $x_{3}$ & & & $\begin{array}{r}12171.7 \\
-1.4\end{array}$ & & & $\begin{array}{r}6924.03 \\
-0.819\end{array}$ & $\begin{array}{r}8735.28 \\
-0.89\end{array}$ \\
\hline The Atkins & $X_{4}$ & & & & $\begin{array}{r}1694.26 \\
-0.206\end{array}$ & $\begin{array}{l}555.71 \\
-0.072\end{array}$ & & $\begin{array}{r}-3317 \\
-0.3753\end{array}$ \\
\hline \multicolumn{9}{|l|}{$10 \% / 1^{\text {st }}$ Quintile } \\
\hline \multicolumn{9}{|l|}{$5 \% 1^{\text {st }}$ Quintile } \\
\hline $\begin{array}{l}\mathrm{R}^{2} \\
\text { Adjusted } \mathrm{R}^{2}\end{array}$ & & $\begin{array}{l}99.10 \% \\
99.08 \%\end{array}$ & $\begin{array}{l}99.24 \% \\
99.21 \%\end{array}$ & $\begin{array}{l}99.14 \% \\
99.10 \%\end{array}$ & $\begin{array}{l}99.10 \% \\
99.06 \%\end{array}$ & $\begin{array}{l}99.24 \% \\
99.19 \%\end{array}$ & $\begin{array}{l}99.25 \% \\
99.20 \%\end{array}$ & $\begin{array}{l}0.9925 \\
0.9919\end{array}$ \\
\hline F statistic & & 5192.6 & 3000.9 & 2650.16 & 2543.4 & 1957.3 & 1986.46 & 1461 \\
\hline $\begin{array}{l}\text { Significance for } \\
F, p \text {-value }\end{array}$ & & $0 \%$ & $0 \%$ & $0.00 \%$ & $0.00 \%$ & $0.00 \%$ & $0.00 \%$ & $0 \%$ \\
\hline Degrees of Fr & & $(1,47)$ & $(2,46)$ & $(2,46)$ & $(2,46)$ & -3.45 & $(3,45)$ & -4.44 \\
\hline
\end{tabular}




\section{Table 01: Equation G1 untransformed GDP/Capita Dependent Variable) (cont.)}

Real (\$2009) GDP/Capita against Real Personal Income/Capita, Various Measures of Inequality

\begin{tabular}{|c|c|c|c|c|c|}
\hline Variables & & $\begin{array}{r}\text { Module } 7 \\
\text { with } 10 \% / 1^{\text {st }} \\
\text { Quintile }\end{array}$ & $\begin{array}{r}\text { Module } 8 \\
\text { with } 5 \% / 1^{\text {st }} \\
\text { Quintile }\end{array}$ & $\begin{array}{r}\text { Model } 9 \text { Year } \\
64-81 \text { with } \\
20 / 20 \text { vs RGC }\end{array}$ & $\begin{array}{l}\text { Model } 10 \text { Years } 64- \\
81 \text { with all the ineq. } \\
\text { measures vs RGC }\end{array}$ \\
\hline Intercept & Bo & $\begin{array}{r}-1793 \\
(-3.12)^{* *}\end{array}$ & $\begin{array}{l}-1081.62 \\
(-2.18)^{* * *}\end{array}$ & $\begin{array}{r}8021.68 \\
(8.087)^{* *}\end{array}$ & -67573 \\
\hline $\begin{array}{l}\text { Real Personal } \\
\text { Income/Capita }\end{array}$ & $\mathrm{X}_{1}$ & $\begin{array}{r}1.002 \\
(31.17)^{* *}\end{array}$ & $\begin{array}{r}0.999 \\
(32.03)^{* *}\end{array}$ & $\begin{array}{r}0.72 \\
(23.9)^{* *}\end{array}$ & \\
\hline 1st/5th Quintiles & $x_{2}$ & & & $28.5(0.4383)$ & $-76.99(0.409)$ \\
\hline The Gini Coefficient & $x_{3}$ & & & & $247165.12(4.723)^{* *}$ \\
\hline The Atkins & $\mathrm{X}_{4}$ & & & & $\begin{array}{r}-78818.2 \\
(-1.43)\end{array}$ \\
\hline $5^{\text {th }} \mathrm{Q} / 1^{\text {st }}$ Quintile & $x_{5}$ & & & & \\
\hline $10 \% / 1^{\text {st }}$ Quintile & & $\begin{array}{r}377.17 \\
(3.99)^{* *}\end{array}$ & & & \\
\hline $5 \% / 1^{\text {st }} \mathrm{Q}$ & & & $\begin{array}{r}266.98 \\
(4.25)^{* *}\end{array}$ & & \\
\hline $\mathrm{R}^{2}$ & & $99.33 \%$ & $99.36 \%$ & $97.48 \%$ & $83.17 \%$ \\
\hline Adjusted $\mathrm{R}^{2}$ & & $99.30 \%$ & $99.33 \%$ & $97.15 \%$ & $79.56 \%$ \\
\hline F statistic & & & & 290.48 & 23.05 \\
\hline $\begin{array}{l}\text { Significance for } F, p \text {-value } \\
\text { Degrees of } F r\end{array}$ & & $\begin{array}{r}0 \% \\
(3,45)\end{array}$ & $\begin{array}{r}0 \% \\
(3,45)\end{array}$ & $\begin{array}{l}0.00 \% \\
(2,15)\end{array}$ & $\begin{array}{l}0.00 \% \\
(3,14)\end{array}$ \\
\hline
\end{tabular}

Model 4 was a combination of RPC, 20/20 and Atkin05. The Atkino5 was not statistically significant. The RPC and 20/20 were significant at the $99 \%$ level. The $\mathrm{R}^{2}$ was $99.19 \%$, not much different from the figure in Model1, 99.21\%.

Model 5 which included the Gini, the 20/20 and RPC was similar to Model 4. The Gini was not significant, and the 20/20 was. The variance inflation ratios were more than 10 each for the Gini and the RPC, indicating collinearity problems.

Model 6 combined all heretofore independent variables against the RGC. The results were more or less as in Model1, showing significance for the 20/20 and the RPC, and essentially the same level of adjusted coefficient of determination. The variance inflation factors for all but the 20/20 were above 10 .

Models 7 and 8 which respectively combined the $10 \% / 1^{\text {st }}$ Quintile and $5 \% / 1^{\text {st }}$ Quintile with RPC showed more statistical significance and higher adjusted coefficient of determination than even Model1. Model 7- a combination of the ratio of the top $10 \%$ of earners to the bottom $20 \%$ (the $1^{\text {st }}$ Quintile), showed statistical significance, $\mathrm{R}^{2}$ of $99.30 \%$, a beta-weight of 0.114 for the $10 \%$ and 0.892 for the RPC. It had a Durbin-Watson of 0.9559 , better than any of the other Models we evaluated, and a variance inflation factor of 5.65 . Model 8 included Top $5 \% / 1^{\text {st }}$ Quintile, showed an, $R^{2}$ of $99.33 \%$, a beta-weight of 0.1179 for the $5 \%$, and a Durbin-Watson of .7315 , the variance inflation factors were 5.496 each, indicating no collinearity problems.

Models 9 \& 10 we explored using the time period 1964-1981 to evaluate the relationships instead of the entire study period of 1964 to 2012. The 20/20 measure showed a positive but statistically insignifant 
relationships (which goes with what we saw on the graph fig 4e). The Gini coefficient was significant and stayed positively related to the Real GDP/Capita. The Atkin05 was insignificant and positively related.

For all the exercises of Table 1 we learn that the 20/20 inequality measure was a better indicator than its counterparts (the Gini and the Atkin05) by itself, and in combination with other independent variables, in having any impact on the overall health of the economy. Small effect in quantity, but the 20/20 measure would seem to show that as inequality increased, GDP/Capita increased.

Table 2 explored the transformed RGC, using Logarithmic functions.

The transformed RGC (in a log-linear relationship), Ln RGC showed a much more statistical significance with the inequality coefficients and their combinations than the untransformed RGC.

We report our findings in Table 2, Models 1 thru 8. If one could equate the In RGC as the change in RGC, we would be able to say that the Atkino5 and the Gini seemed to be more predictive than they were with the untransformed RGC. The Gini showed significance in combination with other measures. The Atkino5 did not show any significance at all. The In (20/20) also showed significance with the Ln RGC, just the same as the ordinary $1^{\text {st }} / 5^{\text {th }}$ would do with the transformed and untransformed RGC.

Table 02: Equation G2 transformed GDP/Capita Dependent Variable Ln Real (\$2009) GDP/Capita against Ln Real Personal Income/Capita, Various Measures of Inequality

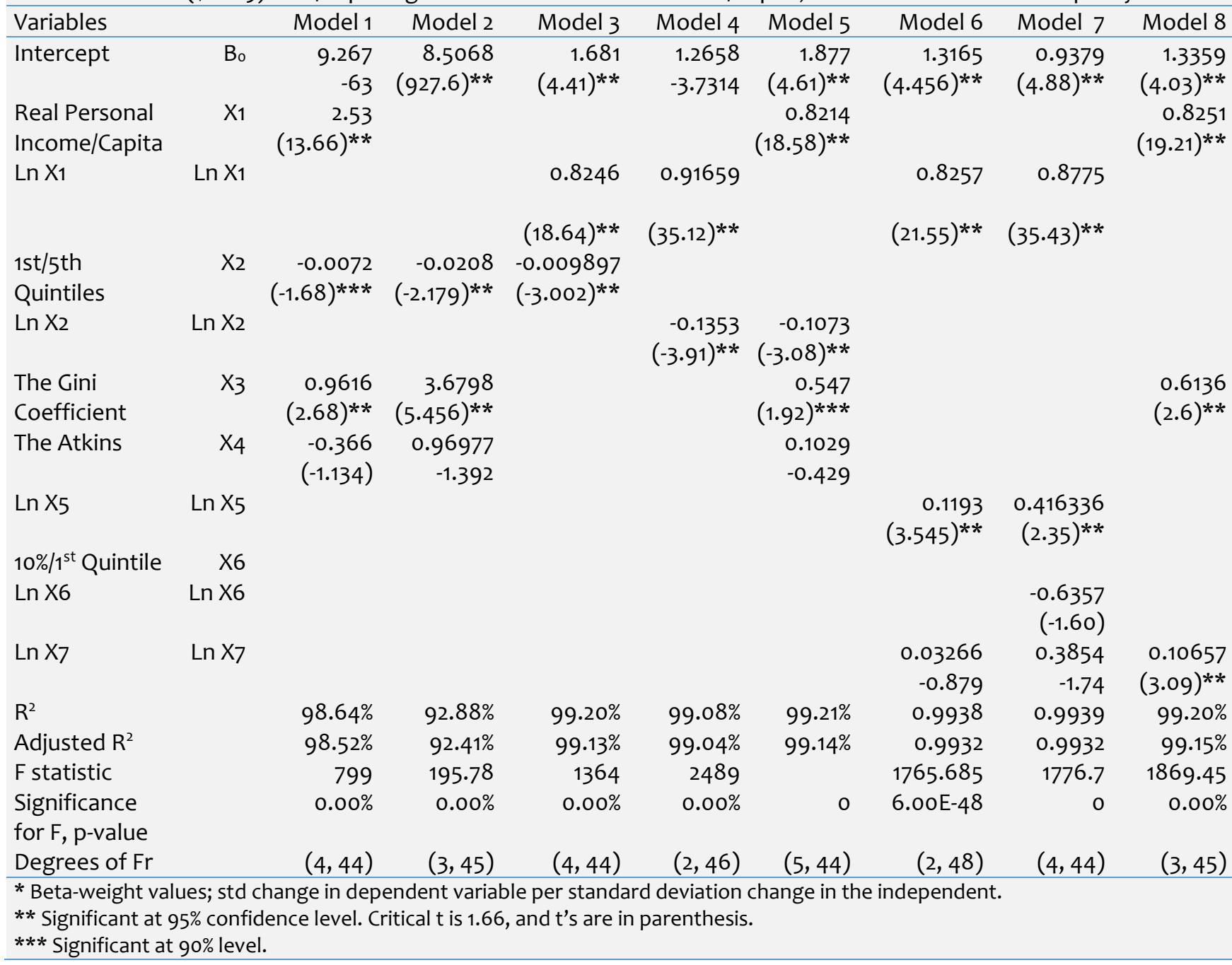

Both the Gini and 20/20 measures were significant in a log-linear analysis. The Gini would seem not to have a linear relationship with Real GDP/Capita. It has a curve-linear relationship. The 20/20 measure has a linear relationship. The Atkino5 was not significant either way. 


\subsection{CONCLUSIONS AND POLICY IMPLICATIONS}

There has been growing income inequality in the US in recent times. Whether one looks at the widening gaps in figures $4 a$ and $4 \mathrm{~b}$, studies the Gini coefficient or the 20/20 ratio, inequality increased steadily throughout the last quarter of the $20^{\text {th }}$ century and beyond.

In the state of New Jersey, the Gini fluctuated between 0.40 and 0.65 . The 20/20 ratio went down from about 0.40 to 0.33 . It is our determination that the inequality measures that were evaluated in this study showed relevance at different inequality manifestations and impacts.

Whereas the 20/20 measure has a relationship with the Real GDP/Capita whether one explores a direct or a log-linear relationship (see Table2), the Gini shows significance in a log-linear relationship only. The most glaring difference is that in many cases, the use of the Gini would tend to indicate that inequality is helpful to economic wellbeing- supporting the Kuznets Curve. The use of the 20/20 measure showed a mixed relationship. Before 1982 the $20 / 20$ measure, in fig. 4 e, varied from a beginning of about $11 \%$ to about $14 \%$ fluctuating along the way, while income growth was in the upward trend, indicating economic growth with decreasing inequality. A statistical analysis done for the 1964-1981 time frame (Model 9 of Table 1) showed a positive, but no statistical significant relationship between 20/20 and GDP/Capita. In which case, during half of the period studied, inequality would seem to reduce growth. After 1982, growth continued even as inequality increased. The statistical analysis showed a significant negative relationship, indicating growth in the economy as inequality worsens, the same indication from the Gini. The 20/20, however would seem to indicate, at least graphically, that at some period in time (between 1964 and 1981 in this case) the GDP would be helped with reduction in inequality.

In the measurement of any effect inequality might have had on state GDP, the 20/20 measure seemed to be the one that showed the most relevance than either the Gini or the Atkin05. The 20/20 measure (the $1^{\text {st }} / 5^{\text {th }}$ ratio) was significant in both the linear model $\left(Y=\beta_{0}+\beta_{i} X_{i}+\varepsilon_{i}\right)$ and the log-linear model $\left(\operatorname{Ln} Y+=\beta_{0}+\right.$ $\left.\beta_{i} X_{i}+\varepsilon_{i}\right)$. Though very small, as to the impact, the $20 / 20$ (X2 in the tables) would change GDP/Capita. $A$ Percent change in the $20 / 20$ ratio would increase Real GDP/Capita by about $0.003 \%$ as calculated in section 4A-2.

We are in a position to argue that the effect of inequality on Real GDP/Capita is so small that economic growth is not a good phenomenon to judge the full effect of income inequality on the society. Other societal ills have to be studied to evaluate the impact of income inequality. It may be creating disfunctional members of the society as suggested by Richard Wilkinson and co. Policy makers should direct their attention accordingly. We will do that in another study.

Some Limitations of the Study: Our studies open the door to further research. The first is that state data at this time is limited, though improving in quality and quantity. Secondly, our study did not separate long term and short term unemployment. Thirdly, we did not massage various transfer payments in and out of the income figures we used. Fourthly, earnings from capital accumulation were not considered, and finally, the top $1 \%$ and top $5 \%$ needed to be explored further, instead of just the top $20 \%$. They might show a much more serious impact than we were able to account for.

\section{References}

Auten, G., (2014), Historical perspectives on income inequality and economic mobility, Income Inequality in America:Fact or Fiction, Economic Policies for the $21^{\text {st }}$ Century at the Manhattan Institute, E21, IssueB \#1, pp 14 - 18

Awuku-Budu, C., Ledia G., Christopher A. L., and Carol A. R., (2013) A first look at experimental personal consumption by expenditures state, BEA Briefing, www.bea.gov/about/pdf/0613_experimental_pcs-by-state_statistics.pdf, (retrieved 08/06/15) 
Barro, R., J. (2000). Inequality and growth in a panel of countries. Journal of Economic Growth 5(1): pp 5-32.

Benoit, K., (2011), Linear regression models with logarithmic transformations, Methodology Institute, London School of Economics. , http://www.kenbenoit.net/courses/ME104/logmodels2.pdf

Birdsall, N., (2007), Income distribution: effects on growth and development, center for global development, Working paper, Number 18, www.cgdev.org

Bishop, J. A. , Subhabrata Chakraborti and Paul D. Thistle, (1991), Relative deprivation and economic welfare: A statistical investigation with gini-based welfare indices, The Scandinavian Journal of Economics, Vol.93, No 3 , http:// www.jstor.org/stable/3440184, retrieved 10/05/2013

Blank, R. M., David C., Frank L. and James M., (1993), Poverty, income distribution and growth: are they still connected?, Brookings Papers on Economic Activity, Vol. 1993, No.2. pp.285-339

Bureau of Economic Analysis, (1963-1997) Gross domestic product (GDP) by state (millions of current dollars), http://bea.gov/regional/pdf/gsp/gdpstate.pdf

Bureau of Economic Analysis GDP by State Estimation Methodology, BEA GDP by State (2014), http://www.bea.gov/newsreleases/regional/gdp_state/gsp_newsrelease.htm

Bureau of Economic Analysis (2014), SA1-3 Personal income summary state or DC, New Jersey, 1929-2013.

Chang, R., (1994), Income inequality and economic growth: evidence and recent theories, Economic Review, Federal Reserve Bank of Atlanta, July - August 1994, pp 1-10

Deaton, A., (2001), Health, inequality, and economic development, National Bureau of Economic Research, Working Paper 8318, htttp://www.nber.org/papers/w8318

De Maio, Fernando G. (2007), Income inequality measures, Dept. of Sociology and Anthropology, J Epidemiol Community Health 2007;61:849-852 .

Frank, Mark W.(2008), A new state level panel of income inequality measures over the period 1916-2005 SHSU Economics \& Int'L Business Working Paper no SHSU_Eco_WPo8-02., Vol.31, pp 241-263, http://www.shsu.edu/eco_mwf/Inequality measures_final.pdf

Frank and Sommeiller (2014) Price Series- Annual top income share measures for each state, 1917-2012, www.shsu.edu/eco.msf/inequality.html

Harkinson, J., (2015), Bernie Sanders goes biblical on income inequality, http://www.motherjones.com/politics/2015/04/bernie-sanders-inequality-president-interview, Mother Jones Publications, (retrieved 08/06/15)

Herb, J., and Raimy S., (2013), Health and safety baseline topic report, Environmental Analysis and Communications Group, Edward J. Bloustein School of Planning and Public Policy, Rutgers University, revised August 2013.

IPUMS - Integrated Public Use Microdata, Minnesota Population Center, University of Minnesota , https:||cps.ipums.org

Kuznets, S., (1955), Economic growth and income inequality, The American Economic Review, Vol.XLV, number one, pp 1-28.

Kuznets Curve from Wikipedia, http://en.wikipedia.org/wiki/Kuznets_curve, retrieved Feb.27, 2015

Lauter, D., (2015), Income inequality emerges as key issue in 2016 presidential campaign, Los Angeles Times,www.latimes.com/nation/la-na-campaign-income-20150205-story-htmlpage=1, Feb. 5, 2015

LSNJ - The Legal Services of New Jersey (2012 and 2014), Income inequality in New Jersey: a growing divide and its consequences, Annual Report from the Legal Services of New Jersey Poverty Research Institute, July 2012 and December 2014.

Odedokun, M.O. and Jeffery I. Round, (2004), Detrminants of Income Inequality and its Effects on Economic Growth: Evidence from African Countries, African Development Bank .

Okpokwasili, B. (2005). Economic growth vs. economic development, a case of Nigeria. In Proceedings of the Association of Global Business, Vol. 17, \#55, Nov. 17-19, 2005.

Panek, S. D., Jacob R H., and Frank T. B. (2003), Comprehensive revision of gross domestic product by metropolitan areas- Advanced Statistics for 2003 and Revised Statistics for 2001-2002

Persson, T., and Guido T., (1994). Is inequality harmful for growth. American Economic Review 84(3): pp 600-621.

Piketty, T., and Emmanuel S., (2003), Income inequality in the United States 1913-1998, The Quarterly Journal of Economics, Vol.CXV111, Issue 1 February 2003. pp 1-39

Sen, A. (2001). Development as Freedom, Oxford University Press. 
Simic, M., (2012) A critical reading of the spirit level: why equality is better for everyone. What is the scientific content of the book?, http://www.environnement.ens.fr/IMG/file/stages/A critical reading of the spirit level

Taylor, T., The Kuznets curve and inequality over the last 100 Years, Conversable Economist, http://conversableeconomist.blogspot.com/211/09/kuznets_curve_and-inequality-over-last.html. Retrieved 02/27/2015

The Manhattan Institute, (2014), E21 Economic Policies for the $21^{\text {st }}$ Century, Income inequality in AmericaFact and Fiction, Issue $B$ \#1

US Department of Commerce, (2012) Household Income Inequality Within US Counties: 2006-2010, United States Census Bureau.

Weil, David N. (2014) A review of Angus Deaton's the great escape: health, wealth and the origins of inequality, Brown University and NBER, Journal of Economic Literature, 53(1): 102-14. DOI: 10.1257/jel.53.1.102

Wilkinson, R and Paul, P.,(2014), What does inequality do to our bodies and minds, a psychologist and an epidemiologist discuss. IDEAS.TED.Com, retrieved 01-09-2016. 